\title{
Anodic and Cathodic Extracellular Electron Transfer by the Filamentous Bacterium Ardenticatena maritima $110 \mathrm{~S}$
}

\begin{abstract}
Satoshi Kawaichi'1f, Tetsuya Yamada 1,2‡, Akio Umezawa ${ }^{1}$, Shawn E. McGlynn ${ }^{1,3}$, Takehiro Suzuki ${ }^{4}$, Naoshi Dohmae ${ }^{4}$, Takashi Yoshida ${ }^{5}$, Yoshihiko Sako ${ }^{5}$, Nobuhiro Matsushita ${ }^{6}$, Kazuhito Hashimoto ${ }^{7}$ and Ryuhei Nakamura ${ }^{1,3 *}$
\end{abstract}

${ }^{1}$ Biofunctional Catalyst Research Team, Center for Sustainable Resource Science, RIKEN, Saitama, Japan, ${ }^{2}$ Department of Electronic Chemistry, Interdisciplinary Graduate School of Science and Engineering, Tokyo Institute of Technology, Tokyo, Japan, ${ }^{3}$ Earth-Life Science Institute, Tokyo Institute of Technology, Tokyo, Japan, ${ }^{4}$ Biomolecular Characterization Unit, Center for Sustainable Resource Science, RIKEN, Wako, Japan, ${ }^{5}$ Laboratory of Marine Microbiology, Graduate School of Agriculture, Kyoto University, Kyoto, Japan, ${ }^{6}$ Department of Materials Science and Engineering, Tokyo Institute of Technology, Tokyo, Japan, ${ }^{7}$ National Institute for Materials Science, Tsukuba, Japan

Ardenticatena maritima strain $110 \mathrm{~S}$ is a filamentous bacterium isolated from an ironrich coastal hydrothermal field, and it is a unique isolate capable of dissimilatory iron or nitrate reduction among the members of the bacterial phylum Chloroflexi. Here, we report the ability of $A$. maritima strain 110 S to utilize electrodes as a sole electron acceptor and donor when coupled with the oxidation of organic compounds and nitrate reduction, respectively. In addition, multicellular filaments with hundreds of cells arranged end-to-end increased the extracellular electron transfer (EET) ability to electrodes by organizing filaments into bundled structures, with the aid of microbially reduced iron oxide minerals on the cell surface of strain 110S. Based on these findings, together with the attempt to detect surface-localized cytochromes in the genome sequence and the demonstration of redox-dependent staining and immunostaining of the cell surface, we propose a model of bidirectional electron transport by A. maritima strain 110S, in which surface-localized multiheme cytochromes and surface-associated iron minerals serve as a conduit of bidirectional EET in multicellular filaments.

\section{Keywords: extracellular electron transfer, filamentous bacteria, iron reducing bacteria, nitrate, cytochromes}

\section{INTRODUCTION}

Redox gradients are generated by a variety of mechanisms in natural environments, and the electrical potential from these gradients can generate electric current, termed geoelectric current, when two such gradients are spatially segregated and electrically connected by a conduit. In some cases, these redox gradients are separated by large distances and can be dissipated by conductive ore bodies in the form of geoelectric currents (Sato and Mooney, 1960). Recently at a smaller scale than ore bodies, in situ experiments have demonstrated that chimney deposits of structured metal sulfide located at deep-sea hydrothermal field are capable of electrically bridging large redox potential which exists between the hot and reduced sulfide bearing hydrothermal fluid flowing within the chimney and the cool and oxic ambient sea water on the outside (Lowy et al., 2006; Nakamura et al., 2009b, 2010; Yamamoto et al., 2013, 2017; Ang et al., 2015; Rowe et al., 2015; Gartman et al., 2017). 
In addition to the abiotically mediated currents mentioned above, geoelectric current derived from biotic metabolism in marine sediments has also been proposed (Nakamura et al., 2009b; Nielsen et al., 2010; Kondo et al., 2015.). For example, sediment dwelling uncultured multicellular filamentous bacteria of the family Desulfobulbaceae have been suggested to couple sulfide oxidation with oxygen or nitrate reduction over microbially large $(>1 \mathrm{~cm}$ ) distances (Nielsen et al., 2010; Pfeffer et al., 2012; Risgaard-Petersen et al., 2012; Schauer et al., 2014; Marzocchi et al., 2014; Larsen et al., 2015; Seitaj et al., 2015; Vasquez-Cardenas et al., 2015; RisgaardPetersen et al., 2015; Sulu-Gambari et al., 2016; Burdorf et al., 2017). Such long-range redox coupling reactions seem to require metabolic synchronization and perhaps metabolic specialization amongst cells within the same filament, since cells on each terminus of the filament could experience very different environments from each other. However, the long-range electron transfer of the multicellular filamentous bacteria remains an open question due to their unculturability and unique structures of insulating surface (Pfeffer et al., 2012). Further, the hypothesis has been challenged by the direct measurement of centimeterlong electron transport through reduced marine sediments: they demonstrated electrical conductivities sufficient for the estimated electron fluxes without any filamentous microbes (Malvankar et al., 2015a,b).

Ardenticatena maritima strain $110 \mathrm{~S}$ is a facultative anaerobic dissimilatory iron-reducing thermophile that forms multicellular filaments composed of hundreds of $0.5 \times 2 \mu \mathrm{m}$ cells arranged end-to-end (Kawaichi et al., 2013a). It inhabits the sediment of a coastal hydrothermal field that contains steep physicochemical gradients (Kawaichi et al., 2013b). There, the exposure of reduced hot fluids to oxic seawater may provide microenvironments with different redox potentials in a narrow area. In static cultures of strain 110S, bundled filamentous structures exceeding $2 \mathrm{~cm}$ in length were observed between the liquid surface and precipitated iron minerals (Figures 1a,b). Furthermore, in contrast to the structure of the typical Gram-negative microorganisms such as Geobacter and Shewanella, A. maritima is presumably monoderm (Kawaichi et al., 2015) similar to the Gram-positive ironreducer Thermincola potens (Wrighton et al., 2011; Carlson et al., 2012) (Figure 1c). For Geobacter and Shewanella species, bacterial outer-membrane (OM) multiheme $c$-type cytochromes (c-cyts) and/or filamentous conductive appendages, so called nanowire, have been identified to mediate extracellular electron transfer (EET) to the surface of $\mathrm{Fe}$ (III) oxides either directly or indirectly via electron shuttles (Reguera et al., 2005; Gorby et al., 2006; Ntarlagiannis et al., 2007; El-Naggar et al., 2010; McLean et al., 2010; Okamoto et al., 2012, 2013; Wegener et al., 2015). However, the unique surface structure of strain $110 \mathrm{~S}$ suggested that if strain $110 \mathrm{~S}$ is capable of performing anodic and cathodic EET using an insoluble electron accepter and donor, respectively, the mechanism for these processes could be distinct from previously described Geobacter and Shewanella species. It is also anticipated that if strain $110 \mathrm{~S}$ is also capable of performing long-range electron transfer, the bundled filamentous structure could couple spatially segregated redox potentials to generate electrical current. In an effort to

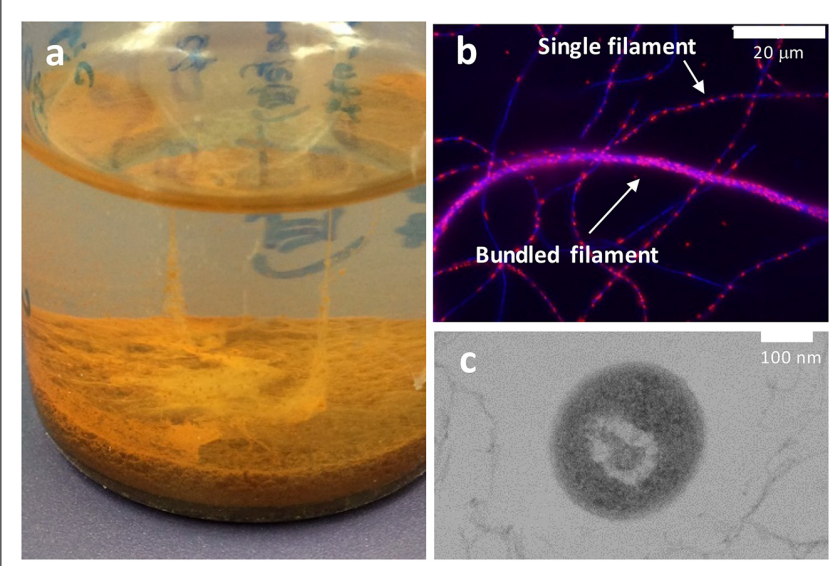

FIGURE 1 | (a) Photograph showing a filamentous structure formed by strain $110 S$ between the surface of the liquid medium and ferrihydrite precipitate. The liquid medium is approximately $2 \mathrm{~cm}$ in depth. (b) Single filaments and a bundled structure of strain 110 S were visualized using an overlay of

$4^{\prime}, 6$-diamidino-2-phenylindole (DAPI, blue) staining and

5-cyano-2,3-di-p-toluyl-tetrazolium chloride (CTC, red) staining. Blue and red spots indicate the localization of double-stranded DNA and $N A D(P) H$,

respectively. (c) Cross-sectional TEM image of strain 110S showing its

smooth surface structure. Scale bars indicate $20 \mu \mathrm{m}$ (b) and $100 \mathrm{~nm}$ (c).

evaluate the potential of the multicellular filamentous bacteria to electrically bridge two redox environments, here we cultivated strain $110 \mathrm{~S}$ in a three-electrode electrochemical cell (EC cell) and investigated the bidirectional EET ability by measuring generation of anodic and cathodic current. Additionally, to advance our understanding of the distant electron transfer, we identified possible heme binding proteins which could facilitate electron transfer and investigated their location within the filaments of strain $110 \mathrm{~S}$.

\section{MATERIALS AND METHODS}

\section{Bacterial Strain and Culture Conditions}

Ardenticatena maritima strain $110 \mathrm{~S}^{\mathrm{T}}$ (NBRC 107679) was routinely cultivated at $60^{\circ} \mathrm{C}$ under aerobic conditions in liquid medium of $100 \mathrm{ml}$ filtrated autoclaved Marine Broth 2216 (Difco) in a 300-ml conical flask. The suspension at an optical density at $600 \mathrm{~nm}\left(\mathrm{OD}_{600}\right)$ was centrifuged $(5,000 \times g$ for $5 \mathrm{~min})$ and the cells were then washed with Marine Broth which lacks both ferric citrate and organic complex for three times prior to use in electrochemical experiments.

\section{Anodic and Cathodic Current Measurements}

A three-electrode EC cell (8 $\mathrm{ml}$ capacity) was assembled using a platinum wire and $\mathrm{Ag} / \mathrm{AgCl} /$ saturated $\mathrm{KCl}$ as counter and reference electrodes, respectively. An optically transparent conducting glass substrate [fluorine-doped tin oxide (FTO)-coated glass electrode, resistance: $20 \Omega /$ square, size: $30 \mathrm{~mm} \times 30 \mathrm{~mm}$; SPD Laboratory, Inc.] with a surface area of $1.8 \mathrm{~cm}^{2}$ was placed on the bottom surface of the reactor 
as the working electrode. A 16-chanel potentiostat (VMP3; BioLogic) was used as an automatic polarization system. For the anodic EET experiments, $5 \mathrm{ml}$ of electrolyte (autoclaved Marine Broth 2216 lacking ferric citrate, followed by $0.22-\mu \mathrm{m}$ syringe filtration) was added to an EC cell and was then purged with pure-nitrogen gas to displace oxygen for $>30 \mathrm{~min}$. In this electrolyte, peptone $(5 \mathrm{~g} / \mathrm{L})$ and yeast extract $(5 \mathrm{~g} / \mathrm{L})$ serves as an electron donor. For the cathodic EET experiments, $5 \mathrm{ml}$ of an autoclaved sodium chloride solution $[3 \%(\mathrm{w} / \mathrm{v})]$ was added to an EC cell as electrolyte and purged with pure-nitrogen for $>30 \mathrm{~min}$. Here, sodium nitrate (final concentration, $5 \mathrm{mM}$ ) was used as an electron acceptor and no organic substrates were added in the EC cell. In all electrochemical experiments, the reactor temperature was maintained at $60^{\circ} \mathrm{C}$ and no agitation was made during the measurements. To evaluate the effects of insoluble iron minerals on the current generation of strain 110S, ferrihydrite $(2.5$, and $10 \mathrm{mM})$, or hematite $(10 \mathrm{mM})$ was added to the electrolyte, and anodic current was measured.

\section{UV/Vis Spectroscopy}

Microbial cells were collected by centrifugation $(3,000 \times g$ for $5 \mathrm{~min}$ ), re-suspended in filtrated fresh Marine Broth 2216 to an $\mathrm{OD}_{600}$ of 24, and then added into a Pyrex cell with an optical path length of $1 \mathrm{~mm}$. The Pyrex cell was then mounted in front of an integrating sphere to measure diffuse light transmission (Nakamura et al., 2009a).

\section{Identification of Membrane-Bound c-cyts}

To isolate membrane-bound proteins, strain $110 \mathrm{~S}$ cells were sonicated and separated into soluble and insoluble fractions by centrifugation $(20000 \times \mathrm{g}$ for $30 \mathrm{~min})$. Proteins in each fraction (crude extract, soluble fraction, and insoluble fraction) were separated by SDS-PAGE. In-gel heme-staining was performed based on the peroxidase activity of $c$-cyt proteins. Bands specific to the insoluble fraction (Supplementary Figure S5) were excised and digested with a trypsin. The digested peptides were separated by nano ESI spray column $(75 \mu \mathrm{m}$ [ID] $\times 100 \mathrm{~mm}$ [L], NTCC analytical column C18, $3 \mu \mathrm{m}$, Nikkyo Technos) with a linear gradient of $0-35 \%$ buffer B (100\% acetonitrile and $0.1 \%$ formic acid) for $10 \mathrm{~min}$ at a flow rate of $300 \mathrm{~nL} / \mathrm{min}$ (EASY-nLC 1000 Liquid Chromatograph, Thermo Fisher Scientific). Eluted peptides were analyzed on line by tandem mass spectrometry. The mass spectrometer ( $\mathrm{Q}$ Exactive mass spectrometer, Thermo Fisher Scientific) was operated in the positive-ion mode, and the MS and MS/MS spectra were acquired using a datadependent TOP10 method (Michalski et al., 2011). The resulting data were searched against a protein database for strain $110 S$ using Mascot Server software (Matrix Science) with variable modifications parameters [Acetyl (Protein N-term), Gln- > pyro-Glu (N-term Q), Deamidated (NQ), Oxidation $(\mathrm{M})$, Propionamide $(\mathrm{C})$ ]. Detected proteins lacking a hemebinding motif, and a signal sequence were omitted and listed in Table 1.

\section{Immunostaining}

Two polyclonal antibodies against ARMA_0580 protein were prepared by Sigma-Aldrich Japan (Tokyo, Japan). Briefly, two

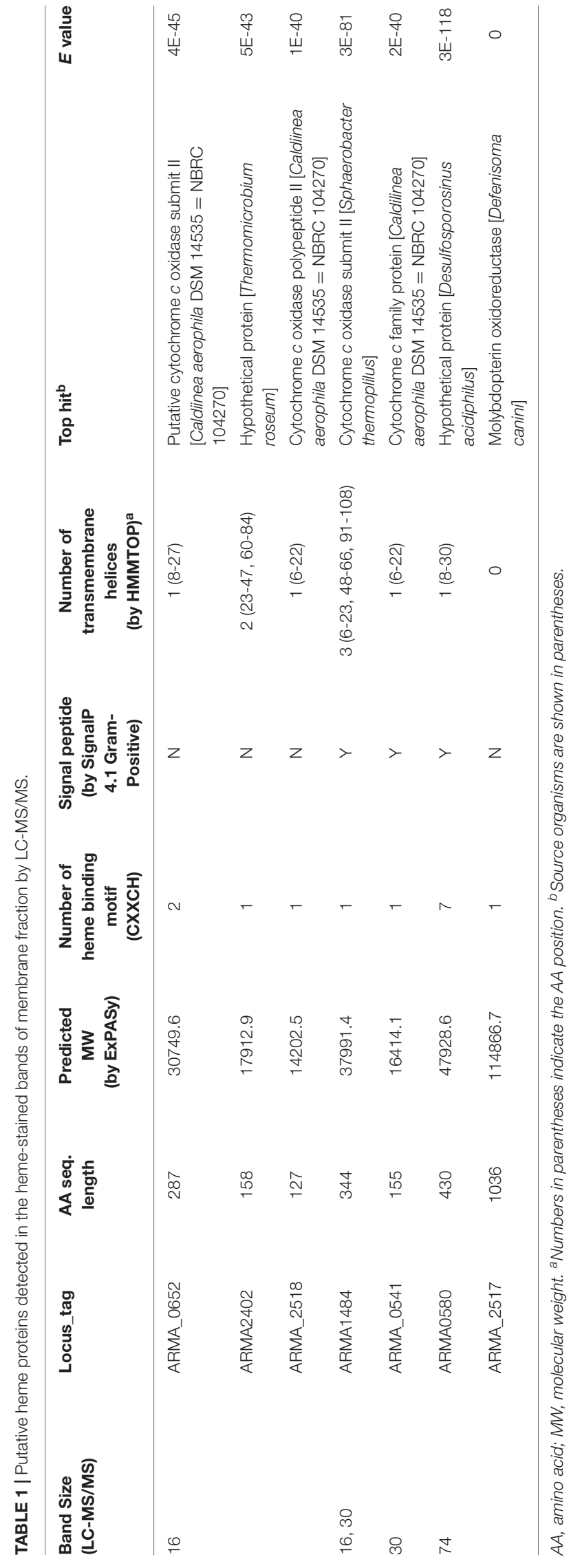


antigenic sites (amino acid numbers 148-161 and 350-385) were identified in silico based on the amino acid sequence derived from the genome sequence of A. maritima strain $110 \mathrm{~S}$. Antibodies were then generated against synthesized peptides in rabbits immunized with synthesized oligopeptides for each antigenic site conjugated with keyhole limpet hemocyanin as a carrier protein. Intact cells of strain 110S have been suspended in PBS buffer. Antiserum solutions containing the target antibodies were added to samples at final concentration of $1 \%(\mathrm{v} / \mathrm{v})$. After overnight incubation at RT, the serum solution was removed, and the cells were washed three times with PBS. Fluorescein isothiocyanate (FITC)-labeled anti-rabbit IgG antibody solution (diluted 1:320 in PBS) was added to each sample, which were then further incubated for overnight at RT. The antibody solution was removed by washing 3 times with PBS, and the stained cells were collected by filtration for microscopic observation. Confocal images were acquired with a Zeiss LSM 710 microscope (Carl Zeiss Inc., Germany) equipped with an argon laser.

\section{TEM Sample Preparation and Observation}

Cells were transferred with a pipet onto a glass slide in an area of approximately $2 \mathrm{~mm}$ in diameter and then overlaid with molten agar (2\% noble agar in $100 \mathrm{mM}$ HEPES buffer solution ( $\mathrm{pH} 8.0$ ) containing $20 \mathrm{~g} / \mathrm{L} \mathrm{NaCl}$ ). The agar plug was removed from the glass slide after solidifying, and was then sliced into small pieces. Agar blocks with enrobed cells were then fixed with $2 \%$ paraformaldehyde and $1.25 \%$ glutaraldehyde in $87 \mathrm{mM}$ HEPES at $\mathrm{pH} 8$ and $12.5 \mathrm{~g} / \mathrm{L} \mathrm{NaCl}$ for $75 \mathrm{~min}$ on ice. After fixation, the filaments were washed five times with $1 \mathrm{ml}$ of $100 \mathrm{mM}$ HEPES buffer solution ( $\mathrm{pH}$ 8) containing $20 \mathrm{~g} / \mathrm{L}$ $\mathrm{NaCl}$, followed by two additions and removals of $50 \mathrm{mM}$ Tris. A solution of 3,3'-diaminobenzidine tetrahydrochloride (DAB; Sigma-Aldrich, St. Louis, MO, United States) was prepared in $1 \mathrm{M} \mathrm{HCl}$ using sonication to dissolve the $\mathrm{DAB}$ powder at a concentration of $0.053 \mathrm{mg} / \mathrm{ml}$. The DAB solution was then diluted into $50 \mathrm{mM}$ Tris- $\mathrm{HCl}(\mathrm{pH}$ 8) to achieve a final concentration of $0.0015 \mathrm{~g} \mathrm{DAB} / \mathrm{ml}$ buffer. The solution was briefly sonicated and immediately filtered through a $0.22-\mu \mathrm{m}$ syringe filter. $\mathrm{H}_{2} \mathrm{O}_{2}$ (30\% aqueous stock) was added to the $\mathrm{DAB}$ solution to achieve a final concentration of $0.02 \%$. The $\mathrm{H}_{2} \mathrm{O}_{2} / \mathrm{DAB}$ solution was added to the samples of sliced agar containing the microbial filaments and incubated on a rocker for $2.5 \mathrm{~h}$ at RT. A DAB solution prepared without $\mathrm{H}_{2} \mathrm{O}_{2}$ was added to parallel samples as a negative control to enable visualization of Osmium binding in the absence of the DAB reaction product. The DAB solution was removed by 5 washes with $100 \mathrm{mM}$ HEPES buffer ( $\mathrm{pH}$ 7.8). An $\mathrm{OsO}_{4}$ solution (1\% in $100 \mathrm{mM}$ HEPES buffer) was added to each sample for staining. The samples were washed by pelleting and re-suspension $3 \times 1 \mathrm{ml}$ with $50 \mathrm{mM}$ Tris $\mathrm{pH} 8.0$, then $3 \times 1 \mathrm{ml}$ with $50 \mathrm{mM}$ HEPES pH 7.8. Finally the agar blocks were embedded into LR White Resin by treatment with a graded ethanol series (15 min each of 25\%, 50, $75,100,100,100 \%)$, followed by treatment with 50\% LR White Resin and $50 \%$ ethanol on a rocker for $30 \mathrm{~min}$. The samples were then transferred to $100 \%$ LR White Resin for $1 \mathrm{~h}$ on a rocker followed by replacement of the resin with fresh $100 \%$ LR white resin and further incubation at $56^{\circ} \mathrm{C}$ for 2 days for polymerization.

TEM of 200-nm thin sections was performed on an LEICA EM UC7 (Leica Microsystems, Germany) with a Histo Diamond knife (EMS). The sections were mounted on copper grids that had been briefly flamed and rinsed in water to make hydrophilic, and were examined and imaged by a JEOL JEM-1400 at $80 \mathrm{kV}$.

\section{RESULTS}

\section{Anodic and Cathodic EET}

We evaluated the anodic EET ability of strain $110 \mathrm{~S}$ $\left(\mathrm{OD}_{600}=1.0\right)$ cultivated anaerobically in a temperaturecontrolled electrochemical cell with a single chamber and three electrodes. Complex organic compound consisted of peptone and yeast extract and an FTO electrode was the sole electron donor and acceptor, respectively. At an applied potential of $+200 \mathrm{mV}$ (vs. $\mathrm{Ag} / \mathrm{AgCl}$ sat. $\mathrm{KCl}$ ), anodic current was generated immediately after cell inoculation at $60^{\circ} \mathrm{C}$, and gradually increased over time (trace 1, Figure 2A). No current increase was observed following the addition of heat-killed cells, indicating that the observed catalytic current was generated by the metabolic activity of intact cells (trace 2, Figure 2A) (Repeat experiments on microbial current generation are available in Supplementary Figure S3). The anodic current displayed a clear potential dependency, and the onset and optimum potentials of the anodic EET of strain $110 \mathrm{~S}$ were estimated to be in the range of -200 to $-100 \mathrm{mV}$ and +300 to $+400 \mathrm{mV}$, respectively (Figure 2B). The observed onset potential was consistent well with the midpoint potential estimated from cyclic voltammetry of intact cells (CV; $E_{1 / 2}=-150 \mathrm{mV}$; Figure $\left.2 \mathrm{C}\right)$. The maximum current density $\left(0.83 \mu \mathrm{A} \mathrm{cm}^{-2}\right)$ obtained in the range of +300 to $+400 \mathrm{mV}$ is approximately 10 -fold and 30 -fold lower than that observed for Shewanella oneidensis and Geobacter sulfurreducens cells, respectively, cultured in the same electrochemical reactor used in the present experiments (Okamoto et al., 2013, 2014).

EET by strain $110 \mathrm{~S}$ was also detected under cathodic conditions using an FTO electrode and nitrate as the sole electron donor and acceptor, respectively. The draft genome of strain $110 \mathrm{~S}$ harbors a complete set of genes (napAB, nirK, norBC, and $n o s Z$ ) for denitrification from nitrate to dinitrogen (Kawaichi et al., 2015). To maximize the cathodic EET, no electron donor (complex organic compound) was added in the EC cell. At an applied potential of $-100 \mathrm{mV}$ (vs. $\mathrm{Ag} / \mathrm{AgCl}$ sat. $\mathrm{KCl}$ ), the cathodic current was gradually increased after inoculation of the intact cells of strain $110 \mathrm{~S}$ at $60^{\circ} \mathrm{C}$ to the EC cell (trace 1 , Figure 2D). The generation of cathodic current was suppressed without nitrate (trace 2, Figure 2D), confirming that cathodic EET from the electrode to the bacterial filament was metabolically coupled with nitrate reduction. Heat-killed cells also generated a small cathodic current of approximately one third of the biotic current, and it gradually decreased over time but did not reach the baseline (trace 3, Figure 2D). This abiotic current may have been generated by heat-tolerant redox active molecules, such as free iron ions released from heme-containing proteins. The 

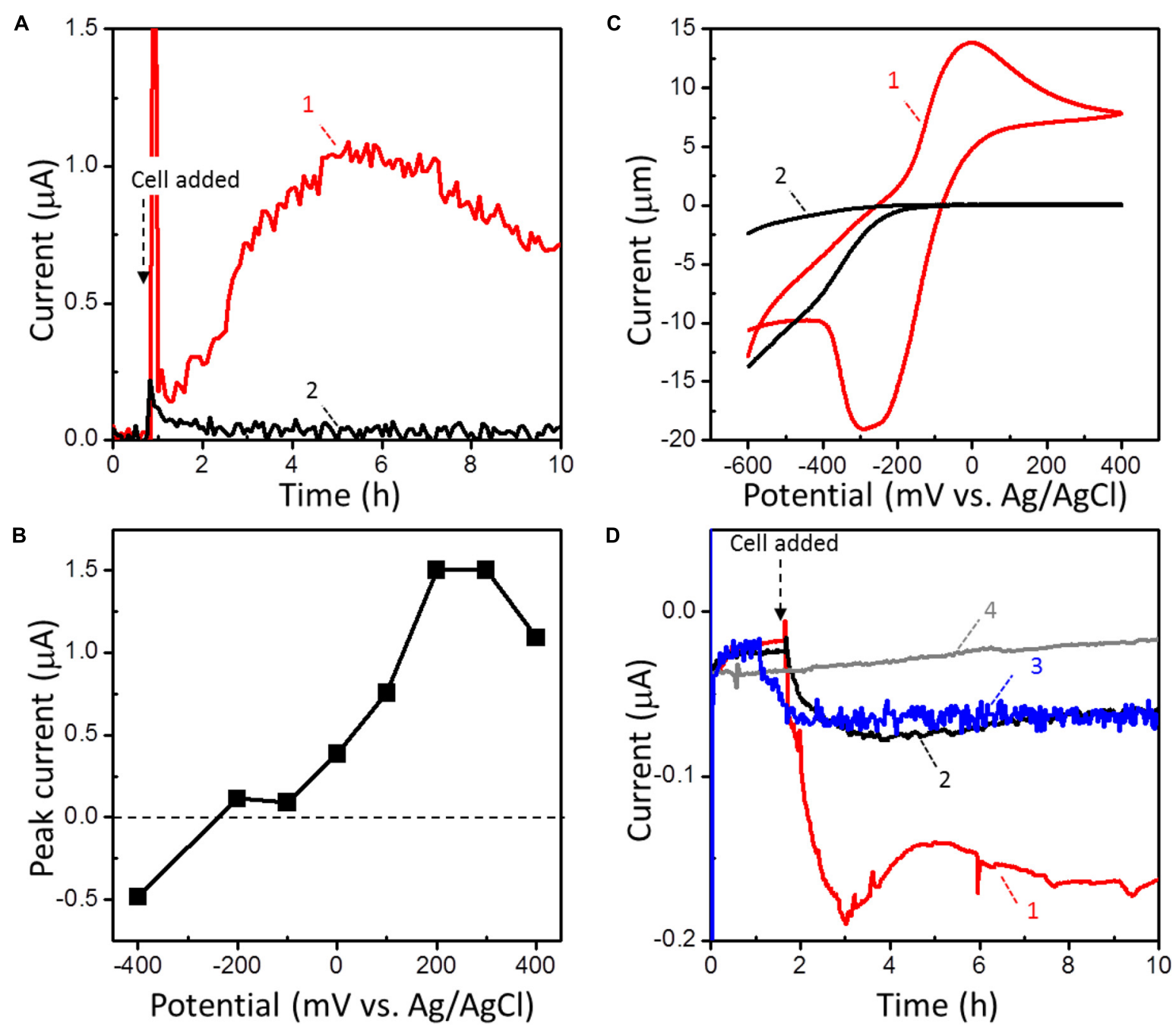

FIGURE 2 | (A) Current (I) vs. time ( $t$ ) measurements of microbial anodic current generation for intact (trace 1) and heat-killed (trace 2) strain 110S on an FTO electrode at +200 (mv vs. Ag/AgCl sat. $\mathrm{KCl}$ ). Cell density was adjusted to $\mathrm{OD}_{600}=1$. (B) The potential dependence of the peak current for the microbial anodic current generation by strain 110S. (C) Whole-cell CVs (scan rate $1 \mathrm{mV} / \mathrm{s}$ ) in the presence (trace 1) and absence (trace 2) of strain 110S cells. Cell density was adjusted to $\mathrm{OD}_{600}=10$. The cathodic current observed for the reactor without cells (trace 2) is not due to the reduction of oxygen, but likely attributable to the substrates present in Marine Broth 2216. (D) / vs. $t$ measurements of microbial cathodic current generation by strain $110 \mathrm{~S}$ on an FTO electrode at -100 mV. / vs. $t$ curves was measured in the presence (trace 1) and absence (trace 2) of nitrate $(5 \mathrm{mM}$ ) as an electron acceptor. Cell density was adjusted to OD $600=2$. Trace 3 is the current generation by heat-killed cells. The back ground current measured without any inoculation was also shown in trace 4 .

back ground current measured without any inoculation was approximately one fifth of the biotic current (trace 4, Figure 2D).

\section{Effects of Fe Minerals on EET}

Since strain $110 \mathrm{~S}$ inhabits an iron-rich sediment and has the ability to reduce extracellular iron minerals (Kawaichi et al., 2013a), we evaluated its EET ability in the EC cell with hematite and ferrihydrite. In this experiment, ferrihydrite (2.5 and $10 \mathrm{mM})$ or hematite $(10 \mathrm{mM})$ was added to the EC cell, and generation of anodic current was measured with a poised potential of $+200 \mathrm{mV}$ in the presence of complex organic compounds. The addition of hematite and ferrihydrite significantly increased anodic current generated by strain 110S (Figure 3). After reaching the current maxima, the current decreased gradually, which could be correlated with the decrease in the amount of organic substrates (electron donor), since a re-injection of complex organic compound resulted in the recovery of microbial current (Supplementary Figure S1). It was also confirmed that the enhanced anodic current generation is due to the synergetic effect of microbial respiration and iron oxides, as neither the addition of ferrihydrite nor hematite alone generates anodic current (Supplementary Figure S2). In addition to the enhanced current generation, the duration of current generation was extended with increasing amounts of added ferrihydrite. Compared to hematite, ferrihydrite had a greater effect on both the amount and length of current generation. In particular, strain $110 \mathrm{~S}$ inoculated in the EC cell with $10 \mathrm{mM}$ ferrihydrite was capable of maintaining current generating over $150 \mathrm{~h}$ (Figure 3, trace 1), which is distinct 


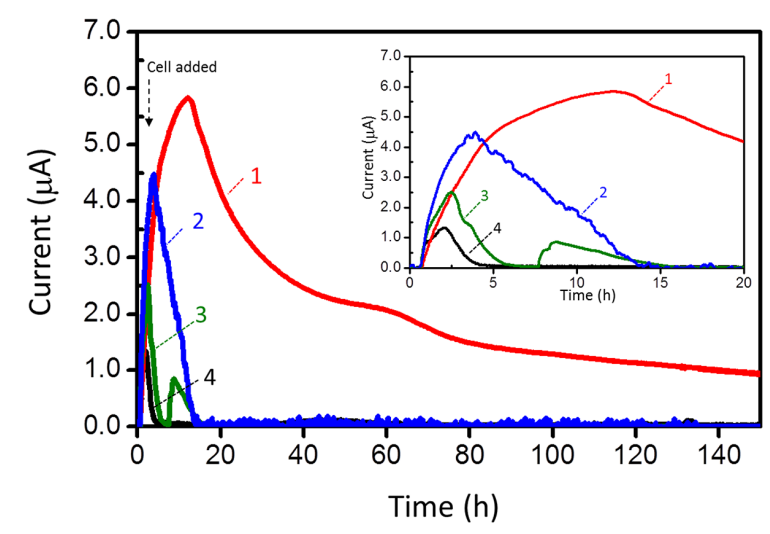

FIGURE 3 | Anodic current ( $($ ) vs. time ( $t)$ measurements for 110 S cultures containing ferrihydrite (trace 1: $10 \mathrm{mM}$, trace 2: $2.5 \mathrm{mM}$ ) and hematite (trace 3: $10 \mathrm{mM}$ ). Current generation in the absence of iron oxides was also shown in trace 4 . Electrode potential was $+200 \mathrm{mV}$. Cell density was adjusted to $\mathrm{OD}_{600}=2$.

from the EC cells lacking ferrihydrite where current rapidly decreased and reached zero after $5 \mathrm{~h}$ of inoculation (Figure 3, trace 4) (Repeat experiments on microbial current generation in the presence of ferrihydrite are available in Supplementary Figure S3).

After inoculating strain $110 \mathrm{~S}$ to the EC cell, the cells were stained with 5-cyano-2,3-di-p-toluyl-tetrazolium chloride (CTC) and $4^{\prime}, 6$-diamidino-2-phenylindole (DAPI) to count viable cells. The proportion of respiring cells estimated by the number of CTC-stained cells divided by DAPI-stained cells detected in the presence of $10 \mathrm{mM}$ ferrihydrite was $51.3 \%$ and $33.6 \%$ after 20 and $140 \mathrm{~h}$ of inoculation, respectively. Those values were larger than those observed for the cells cultivated without ferrihydrite (17.8 and $0 \%$ after 20 and $140 \mathrm{~h}$, respectively). Thus, the enhanced anodic current suggests that the addition of ferrihydrite increased the number of viable cells in the multicellular filament which is capable of maintaining respiratory activity via electron transport to a distant electrode.

The onset potential for current generation was estimated from the potential-dependent current generation curves $(-200 \mathrm{mV}$ to $-100 \mathrm{mV}$, Figure 2B) and CV (Figure 2C). It is consistent well with the redox potential of ferrihydrite which ranges between -100 and $100 \mathrm{mV}$ vs. SHE $(-300$ to $-100 \mathrm{mV}$ vs. $\mathrm{Ag} / \mathrm{AgCl}$ sat. $\mathrm{KCl}$ ), whereas that of hematite is more negative $(-287 \mathrm{mV}$ vs. SHE [ $-487 \mathrm{mV}$ vs. $\mathrm{Ag} / \mathrm{AgCl}$ sat. $\mathrm{KCl}]$ ) (Thamdrup, 2000; Straub et al., 2001). Thus, the enhanced anodic EET by ferrihydrite suggests that strain $110 \mathrm{~S}$ cells utilize cell-surface associated ferrihydrite as a conduit of electron transport via a multistep redox hopping mechanism, as was observed for Shewanella species (Nakamura et al., 2009b, 2013). Although ferrihydrite is known to be a poor electron conductor, its ability for transporting electron is improved by strain $110 \mathrm{~S}$ due to the microbial reduction of ferrihydrite (Supplementary Figure S4) [Direct electrochemical reduction of ferrihydrite or hematite was excluded, as no cathodic current was observed in the absence of bacterial cells (Supplementary Figure S2)]. It is therefore expected that the cell-surface associated ferrihydrite increased the number of cells in the multicellular filments that can participate in electrical current generation.

\section{Conductive Measurement of Intact Microbial Filaments}

To measure the conductivity of the filamentous structures of strain 110S, whole cells were washed to remove the culture medium and extracellular molecules, and were then mounted on a two-electrode system consisting of micro-fabricated platinum electrode deposited on a fused quartz substrate (Supplementary Figure S4). To minimize damage to the microbial filaments, the samples were not chemically treated or subjected to criticalpoint drying. Cells were mildly dried under the continuous flow of $100 \%$ nitrogen at room temperature to maintain anaerobic conditions. However, our attempt to get reliable data for the conductivity of intact cells of strain 110 S ended in failure due to the low electrical conductivity of the filaments.

\section{Multiheme Cytochromes}

In the Gram-negative bacterium Shewanella oneidensis, multiheme $c$-cyts in bacterial outer-membrane have been identified to mediate EET to the surface of Fe(III) oxides and electrodes either directly or indirectly via electron shuttles (Myers and Myers, 1992; Magnuson et al., 2001). Multiheme $c$-cyts are also localized along the surface of conductive nanowires, which appear to be extensions of the outer membrane and periplasm (Pirbadian et al., 2014). The localization of $c$-cyts to these membrane extensions provides the most compelling evidence to date for long-range EET, and supports a proposed mechanism of multistep redox hopping (Pirbadian and El-Naggar, 2012) by which electrons are transported along a network of heme cofactors within microbial membrane filaments. Meanwhile, type IV pili and the multiheme $c$-cyts are identified to mediate long-range electron transfer for Geobacter species (Malvankar et al., 2011; Vargas et al., 2013). Here we speculated that multiheme $c$-cyts play a role in the electricity generation of strain $110 \mathrm{~S}$ filaments, and attempted to detect cell-surface multiheme $c$-cyts in this strain using a multidisciplinary approach involving spectroscopy, genetics, biochemistry, and microscopy.

Because of the large molar absorption coefficient of heme irons, UV/Vis spectroscopy is a desirable method for investigating multiheme $c$-cyts in intact cells. To eliminate spectral interference from light scattered by the cell surface, diffuse transmission UV/Vis spectroscopy was performed. In the obtained diffuse transmission spectrum of strain $110 \mathrm{~S}$ (Figure 4a), an intense absorption band at $420 \mathrm{~nm}$ (the Soret band) and weak absorption bands at 522 and $552 \mathrm{~nm}$ (the Q band) were observed. These peak positions are characteristic of the reduced form of heme groups of $c$-cyts (Higuchi et al., 1987; Okamoto et al., 2009). Considering the molar absorption coefficient of the Soret band is an order of $10^{5}$ (Solomon et al., 1992), the concentration of the heme groups in the cell suspension was estimated to be approximately $0.01 \mathrm{mM}$, a value that is 50 times lower than that of Shewanella cells $(0.5 \mathrm{mM})$ (Nakamura et al., 2009a) with the same cell density. 

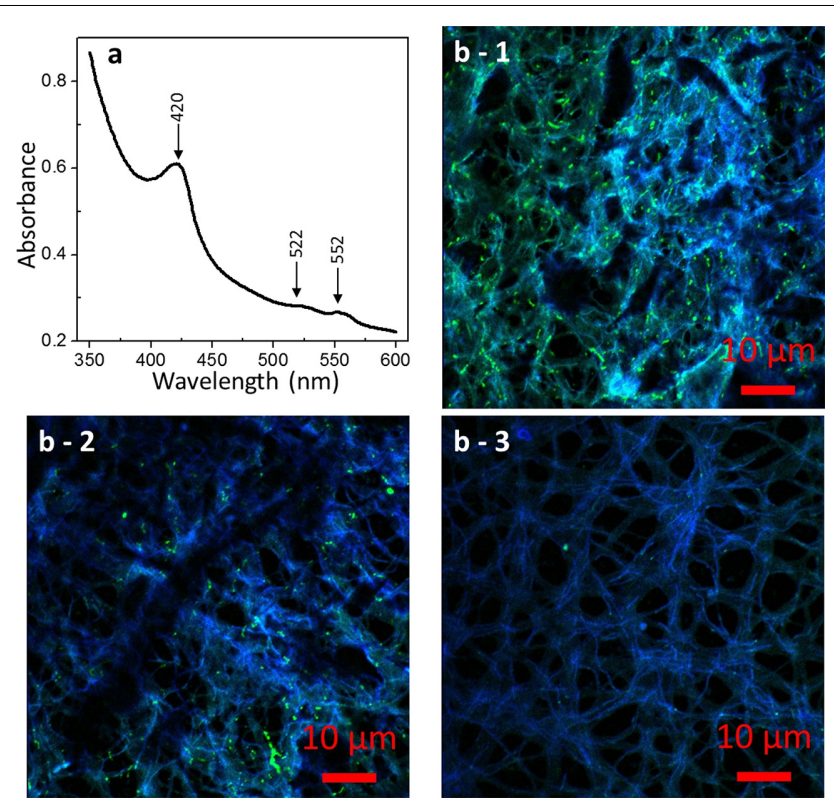

FIGURE 4 | Microscopic images of strain 110S. (a) UVNis spectrum of a whole cell suspension of strain 110S. Absorbance peaks for the Soret band (420 nm) and Q-band (522 and $552 \mathrm{~nm}$ ) of c-cyts were observed. (b) Confocal micrographs of strain 110 S stained with pos_148-161 (b-1) and pos_350-365 (b-2) FITC-labeled polyclonal antibodies against ARMA_0580 protein, or without primary antibody (b-3). Scale bars indicate $10 \mu \mathrm{m}$.

\section{Multiheme Cytochrome Genes in the Genome}

In the draft genome sequence of strain 110S (Kawaichi et al., 2015), 39 coding sequences (CDSs) with heme-binding peptide motifs $(\mathrm{CXXCH})$ (Supplementary Table S1), including nine CDSs for multiheme proteins, were detected among the total of 3,355 predicted CDSs. Among the putative multiheme proteins, four sequences (ARMA_580, ARMA_1428, ARMA_1572, and ARMA_2257) contained a signal peptide sequence, which is necessary for translocation of the protein across the membrane and onto the cell surface. Notably, ARMA_580 contained the highest number (seven) of hemebinding motifs among the putative heme-proteins of strain 110S. A protein BLAST search revealed that this seven-heme protein is most similar to an unidentified hypothetical protein of the Gram-negative bacterium Desulfosporosinus acidiphilus, which is predicted to have iron oxidation/reduction activity based on functional genome distribution analysis (Altermann, 2012, 2014).

Cells of strain $110 \mathrm{~S}$ are stain Gram negative and have a multilayer-like structure consisting of two electron-dense and two electron-transparent layers, as revealed by transmission electron microscopy (TEM) observation (Kawaichi et al., 2013a). However, they are thought to be monoderm, since biochemical and genomic analyses have shown that Chloroflexi lack lipopolysaccharide (LPS) and a number of corresponding biogenesis genes required for the formation of a double membrane (Sutcliffe, 2010, 2011). In the draft genome sequence

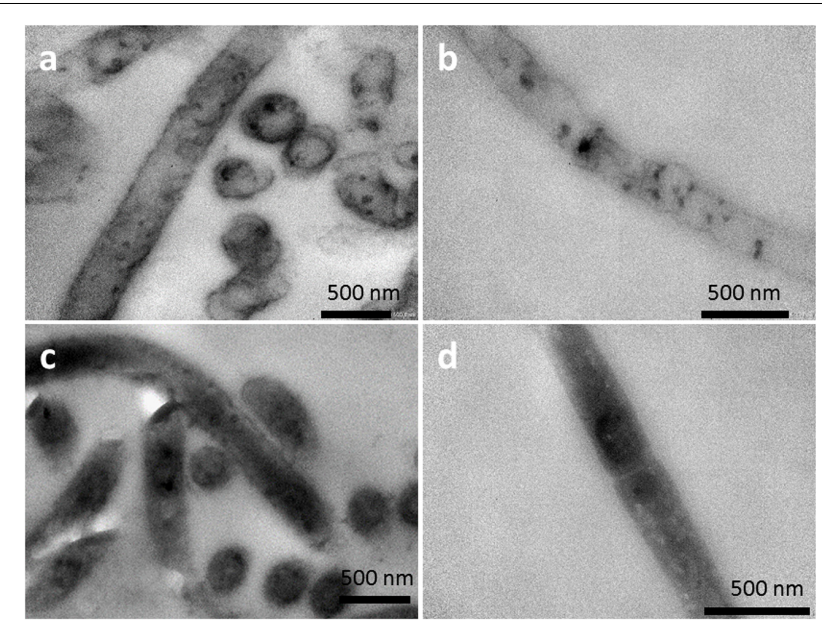

FIGURE $\mathbf{5}$ | TEM images of DAB-stained cells $\mathbf{( a , b )}$ cultivated under anodic EET conditions. Image $\mathbf{( a , b )}$ was obtained in the presence and absence of $\mathrm{H}_{2} \mathrm{O}_{2}$, respectively. As a comparison to electrochemical cultivation, TEM images of DAB-stained cells cultivated anaerobically in a conical flask with LB were shown in (c) and (d). Image (c) and (d) was obtained in the presence and absence of $\mathrm{H}_{2} \mathrm{O}_{2}$, respectively.

of strain 110S, only a few CDSs involved in LPS biogenesis were detected, indicating that this pathway is also defective. In addition, the genome lacked CDSs for the BamA family of proteins, which plays a crucial role in outer membrane biogenesis (Knowles et al., 2009). These data support the monoderm feature of strain 110S. Since we could not isolate outer membrane proteins from cells of strain $110 \mathrm{~S}$ using a preparation method developed for the model Gram-negative bacterium Geobacter sulferreducens (Inoue et al., 2010), sonicated crude cellular extracts were simply separated into soluble and insoluble fractions by centrifugation as an alternative method. Three protein bands with molecular masses of 16,30 , and $74 \mathrm{kDa}$ were specifically detected in the insoluble membrane fraction by in-gel heme staining of SDS-PAGE based on the activity of $c$-cyt heme peroxidase (Supplementary Figure S5) (Goodhew et al., 1986). Using in-gel tryptic digestion and LC-MS/MS, the bands of 16- and 74-kDa heme-stained were identified as ARMA_0652 and ARMA_0580, which is consistent with the prediction above as a heme binding protein with signaling peptide sequence, respectively (Table 1). ARMA_0652 is a hypothetical protein with a sequence similar to the putative cytochrome $c$ oxidase subunit II of Caldilinea aerophila.

To confirm the expression of multiheme $c$-cyts of strain 110 , we performed immunofluorescence microscopy using two polyclonal antibodies targeting ARMA_580, a surface-localized protein with putative seven heme binding. Consistent with the findings from the draft genome analyses, confocal microscopy of bacterial filaments with the primary and secondary antibodies showed FITC fluorescence derived from antibody binding (Figures 4b-1,2). Not all the cells in multicellular filaments were stained by the immunostaining, indicating a functional differentiation or a heterogeneous activity in the filament. This green fluorescence was not observed when the primary antibodies 


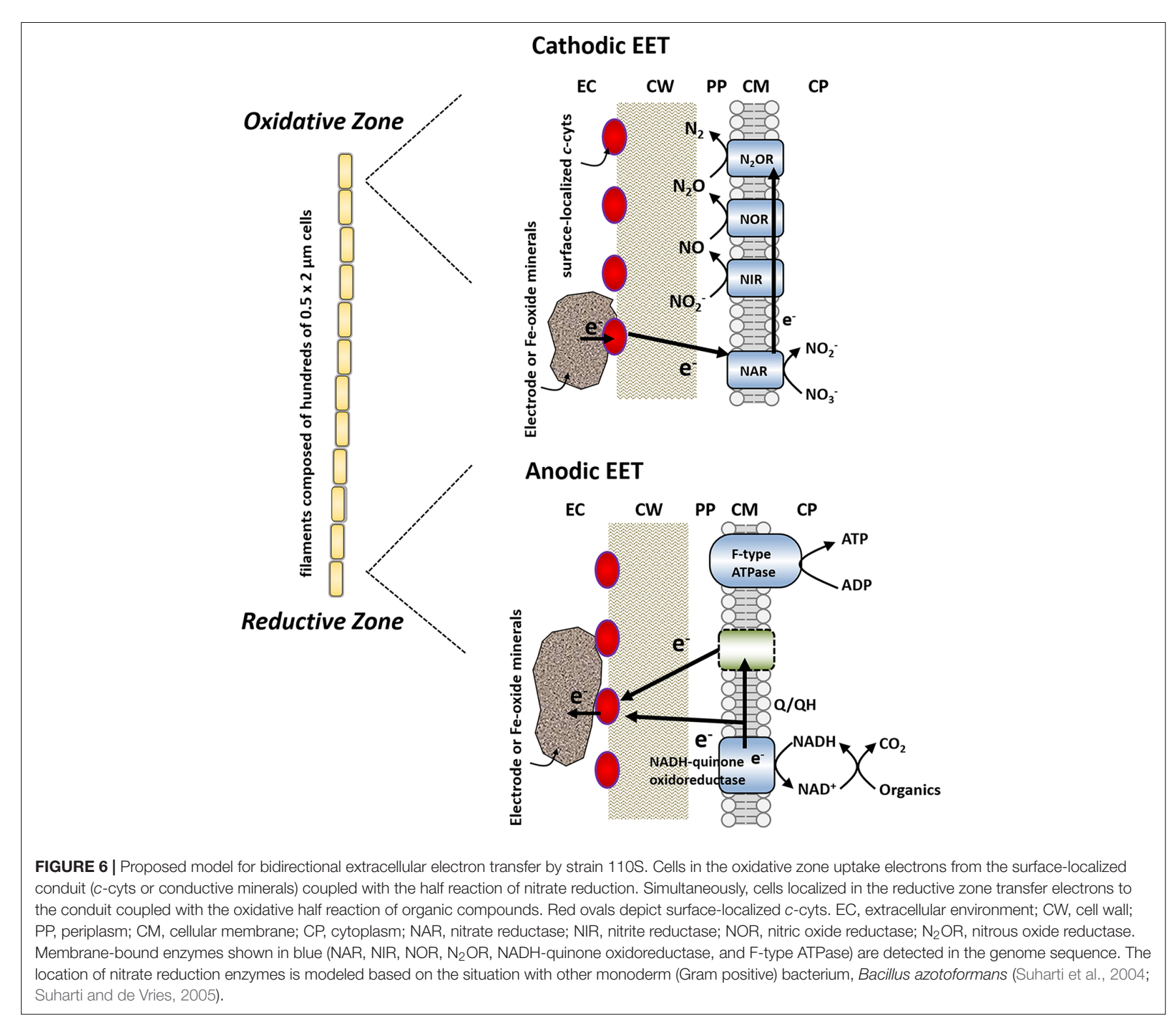

were omitted (Figure $4 \mathbf{b}-\mathbf{3}$ ), nor was a signal observed in control experiments using E. coli (Supplementary Figure S6).

The possibility of heme binding proteins on the cell surface was also investigated by a TEM technique suitable for detecting heme groups (Roels, 1974; Litwin, 1982). Aerobically grown cells of strain $110 \mathrm{~S}$ were placed in an EC cell at an applied potential of $+200 \mathrm{mV}$, fixed with glutaraldehyde, and treated with $3,3^{\prime}$ diaminobenzidine (DAB) followed by post staining with $\mathrm{OsO}_{4}$ (Seligman et al., 1968; McGlynn et al., 2015). TEM analysis of ultrathin sections revealed that a thin dark layer was present on the filament surfaces (Figure 5a), indicative of the presence of heme binding proteins at the cell surface of bacterial filaments (Roels, 1974; Litwin, 1982; McGlynn et al., 2015). This staining derived from DAB oxidation catalyzed by heme with $\mathrm{H}_{2} \mathrm{O}_{2}$ - was not observed when DAB was included in the absence of $\mathrm{H}_{2} \mathrm{O}_{2}$ (Figure 5b). Thus, the contrast between TEM images with and without $\mathrm{H}_{2} \mathrm{O}_{2}$ suggests the location of heme within the filaments of strain 110S. As a comparison, DAB staining experiments were also conducted to the cells cultivated anaerobically in a conical flask with LB (Figures 5c,d). A thin layer of stained material was again observed on the surface when $\mathrm{H}_{2} \mathrm{O}_{2}$ was included. On the other hand, the treatment without $\mathrm{H}_{2} \mathrm{O}_{2}$ was much darker than the anodically (anaerobically) grown cells (compare Figure 5b and Figure 5d), likely due to the activity of a cytochrome c-oxidase protein which may catalyze DAB oxidation even in the absence of $\mathrm{H}_{2} \mathrm{O}_{2}$ (Seligman et al., 1968).

\section{DISCUSSION}

In the present study, we investigated the EET ability and the existence of surface-associated multiheme cytochromes of intact filaments of a pure-cultured filamentous bacterium. We provided evidence that $A$. maritima strain 110 S has the ability to generate 
anodic and cathodic current when coupled with the oxidation of organic compounds and nitrate reduction, respectively (Figure 2). We also genomically identified seven putative heme binding $c$-cyts in strain $110 \mathrm{~S}$, one of them was shown to be expressed, and heme-binding protein(s) was suggested to be localized on the surface of strain 110 S filaments with monoderm structure (Figures 4, 5). The metabolic rate of strain $110 \mathrm{~S}$ calculated from the peak current of the andic EET at $+200 \mathrm{mV}$ and the cell density $\left(10^{2}\right.$ electrons per cell per second, which corresponds to approximately $10^{4}$ electrons per filament per second, Figure 2A) is four orders of magnitude lower than that of S. oneidensis MR-1 ( $10^{6}$ electrons per cell per second) (El-Naggar et al., 2010). However, this microorganism appears to have increased the EET ability by organizing filaments into bundled structures (Figures 1a,b), a possible strategy for achieving a $c$-cyt density allowing electron percolation along entire filaments (Broadbent and Hammersley, 1957). Additionally, the clustering of microbially reduced and conductive iron oxide minerals on the cell surface of strain $110 \mathrm{~S}$ also facilitated electron transfer in the natural environment through self-constructed bacterial networks (Nakamura et al., 2009b, 2013), which may allow strain $110 \mathrm{~S}$ to inhabit an iron-rich sediment with the ability to reduce extracellular iron minerals (Kawaichi et al., 2013b). Consistent with this speculation, ferrihydrite greatly increased both the maximum current generation and dulation of current generation by strain 110S (Figure 3 and Supplementary Figure S3), which in turn resulted in the large increase in the number of viable cells in the multicellular filament. From those results we suggest that cell surface-associated iron-oxide minerals facilitated long-range electron transfer between the electrode and bacterial cells that were not directly in contact with the electrode.

On the basis of the anodic and cathodic EET and the existence of surface-associated multiheme cytochromes, we propose a model of bidirectional EET by the filamentous bacterium A. maritima 110S, as schematically illustrated in Figure 6. In this model, cells localized in the reductive zone transfer electrons to the surface-localized conduit (c-cyts or conductive minerals) coupled with the oxidative half reaction of organic compounds (anodic EET). Simultaneously, cells in the oxidative zone uptake electrons from the extracellular insoluble electron donor coupled with the half reaction of nitrate reduction via the denitrification pathway (napAB, nirK, norBC, and nos $Z$ ) (cathodic EET). Thus, the ability of anodic and cathodic EET facilitate the interface of cellular metabolism with the segregated biogeochemical reactions

\section{REFERENCES}

Altermann, E. (2012). Tracing lifestyle adaptation in prokaryotic genomes. Front. Microbiol. 3:48. doi: 10.3389/fmicb.2012.00048

Altermann, E. (2014). Invited commentary: lubricating the rusty wheel, new insights into iron oxidizing bacteria through comparative genomics. Front. Microbiol. 5:386. doi: 10.3389/fmicb.2014.00386

Ang, R., Khan, U. A., Tsujii, N., Takai, K., Nakamura, R., and Mori, T. (2015). Thermoelectricity generation and electron-magnon scattering in a natural chalcopyrite mineral from a deep-sea hydrothermal vent. Angew. Chem. Int. Ed. 54, 12909-12913. doi: 10.1002/anie.20150 5517 in the sediments of a coastal hydrothermal field (Kawaichi et al., 2013b). Although the present study demonstrated the ability of the multicellular filamentous bacteria to conduct bidirectional EET for dissipating spatially segregated redox potentials in a form of electrical current, no direct evidence for the long-range electron transport along the filament was provided. Further work including the conductivity measurements along the filament and the establishment of a gene manipulation system for strain $110 \mathrm{~S}$ will enable us to detect long-range electrical currents mediated by filamentous bacteria, which will lead to understand the impact of bio-geoelectric currents on chemical cycling.

\section{AUTHOR CONTRIBUTIONS}

$\mathrm{RN}$, SK, TYa, and $\mathrm{KH}$ and conceived and designed the experiments. SK, TYa, AU, TS, ND, SM, and TYo performed the experiments. RN, SK, TYa, AU, TS, ND, SM, NM, TYo, and YS analyzed the data. RN, SK, TYa, and SM wrote the manuscript.

\section{FUNDING}

This work was financially supported by a Grant-in-Aid for Specially Promoted Research from the Japan Society for Promotion of Science (JSPS) KAKENHI Grant Number 24000010, and by a the Grant-in-Aid for Scientific Research (A) (grant 25252038). TYa is supported by a Grant-in-Aid for JSPS Research Fellows (no. 16J09656). SM is supported by KAKENHI Grant-in-Aid for Challenging Exploratory Research (grant award number 15K14608) and also an award from the Research Foundation for Opto-Science and Technology.

\section{ACKNOWLEDGMENTS}

The authors thank Ms. T. Minami of RIKEN for the careful reading of the manuscript.

\section{SUPPLEMENTARY MATERIAL}

The Supplementary Material for this article can be found online at: https://www.frontiersin.org/articles/10.3389/fmicb. 2018.00068/full\#supplementary-material

Broadbent, S. R., and Hammersley, J. M. (1957). Percolation processes. I. Crystals and Mazes. Proc. Camb. Phil. Soc. 53, 629-641. doi: 10.1017/ S0305004100032680

Burdorf, L. D. W., Tramper, A., Seitaj, D., Meire, L., Hidalgo-Martinez, S., Zetsche, E.-M., et al. (2017). Long-distance electron transport occurs globally in marine sediments. Biogeosciences 14, 683-701. doi: 10.5194/bg-14-683-2017

Carlson, H. K., Iavarone, A. T., Gorur, A., Yeo, B. S., Tran, R., Melnyk, R. A., et al. (2012). Surface multiheme $c$-type cytochromes from Thermincola potens and implications for respiratory metal reduction by Gram-positive bacteria. Proc. Natl. Acad. Sci. U.S.A. 109, 1702-1707. doi: 10.1073/pnas.1112905109

El-Naggar, M. Y., Wanger, G., Leung, K. M., Yuzvinsky, T. D., Southam, G., Yang, J., et al. (2010). Electrical transport along bacterial nanowires from Shewanella 
oneidensis MR-1. Proc. Natl. Acad. Sci. U.S.A. 107, 18127-18131. doi: 10.1073/ pnas. 1004880107

Gartman, A., Picard, A., Olins, H. C., Sarode, N., Clarke, D. R., and Girguis, P. R. (2017). Microbes facilitate mineral deposition in bioelectrochemical systems. ACS Earth Space Chem. 1, 277-287. doi: 10.1021/acsearthspacechem.7b00042

Goodhew, C. F., Brown, K. R., and Pettigrew, G. W. (1986). Haem staining in gels, a useful tool in the study of bacterial c-type cytochromes. Biochim. Biophys. Acta 852, 288-294. doi: 10.1016/0005-2728(86)90234-3

Gorby, Y. A., Yanina, S., McLean, J. S., Rosso, K. M., Moyles, D., Dohnalkova, A., et al. (2006). Electrically conductive bacterial nanowires produced by Shewanella oneidensis strain MR-1 and other microorganisms. Proc. Natl. Acad. Sci. U.S.A. 103, 11358-11363. doi: 10.1073/pnas.0604517103

Higuchi, Y., Inaka, K., Yasuoka, N., and Yagi, T. (1987). Isolation and crystallization of high molecular weight cytochrome from Desulfovibrio vulgaris Hildenborough. Biochem. Biophys. Acta 911, 341-348. doi: 10.1016/01674838(87)90075-6

Inoue, K., Qian, X., Morgado, L., Kim, B. C., Mester, T., Izallalen, M., et al. (2010). Purification and characterization of OmcZ, an outer-surface, octaheme c-type cytochrome essential for optimal current production by Geobacter sulfurreducens. Appl. Environ. Microbiol. 76, 3999-4007. doi: 10.1128/AEM. 00027-10

Kawaichi, S., Ito, N., Kamikawa, R., Sugawara, T., Yoshida, T., and Sako, Y. (2013a). Ardenticatena maritima gen. nov., sp. nov., a ferric iron- and nitrate-reducing bacterium of the phylum 'Chloroflexi' isolated from an iron-rich coastal hydrothermal field, and description of Ardenticatenia classis nov. Int. J. Syst. Evol. Microbiol. 63, 2992-3002. doi: 10.1099/ijs.0. 046532-0

Kawaichi, S., Ito, N., Yoshida, T., and Sako, Y. (2013b). Bacterial and archaeal diversity in an iron-rich coastal hydrothermal field in Yamagawa, Kagoshima, Japan. Microbes Environ. 28, 405-413. doi: 10.1264/jsme2.ME13048

Kawaichi, S., Yoshida, T., Sako, Y., and Nakamura, R. (2015). Draft genome sequence of a heterotrophic facultative anaerobic thermophilic bacterium, Ardenticatena maritima strain $110 \mathrm{~S}^{\mathrm{T}}$. Genome Announc. 3:e1145-15. doi: 10.1128/genomeA.01145-15

Knowles, T. J., Scott-Tucker, A., Overduin, M., and Henderson, I. R. (2009). Membrane protein architects: the role of the BAM complex in outer membrane protein assembly. Nat. Rev. Microbiol. 7, 206-214. doi: 10.1038/nrmicro 2069

Kondo, K., Okamoto, A., Hashimoto, K., and Nakamura, R. (2015). Sulfurmediated electron shuttling sustains microbial long-distance extracellular electron transfer with the aid of metallic iron sulfides. Langmuir 31, 7427-7434. doi: 10.1021/acs.langmuir.5b01033

Larsen, S., Nielsen, L. P., and Schramm, A. (2015). Cable bacteria associated with long-distance electron transport in New England salt marsh sediment. Environ. Microbiol. Rep. 7, 175-179. doi: 10.1111/1758-2229.12216

Litwin, J. A. (1982). Transition metal-catalysed oxidation of 3,3' -diaminobenzidine [DAB] in a model system. Acta Histochem. 71, 111-117. doi: 10.1016/S00651281(82)80023-8

Lowy, D. A., Tender, L. M., Zeikus, J. G., Park, D. H., and Lovley, D. R. (2006). Harvesting energy from the marine sediment-water interface II. Kinetic activity of anode materials. Biosens. Bioelectron. 11, 2058-2063. doi: 10.1016/j.bios. 2006.01.033

Magnuson, T. S., Isoyama, N., Hodges-Myerson, A. L., Davidson, G., Maroney, M. J., Geesey, G. G., et al. (2001). Isolation, characterization and gene sequence analysis of a membrane-associated $89 \mathrm{kDa} F($ III) reducing cytochrome $c$ from Geobacter sulfurreducens. Biochem. J. 359, 147-152.

Malvankar, N. S., King, G. M., and Lovley, D. R. (2015a). Centimeter-long electron transport in marine sediments via conductive minerals. ISME J. 9, 527-531. doi: $10.1038 /$ ismej.2014.131

Malvankar, N. S., Vargas, M., Nevin, K., Tremblay, P. L., Evans-Lutterodt, K., Nykypanchuk, D., et al. (2015b). Structural basis for metallic-like conductivity in microbial nanowires. mBio 6:e84-15. doi: 10.1128/mBio.00084-15.Editor

Malvankar, N. S., Vargas, M., Nevin, K. P., Franks, A. E., Leang, C., Kim, B. C., et al. (2011). Tunable metallic-like conductivity in microbial nanowire networks. Nat. Nanotechnol. 6, 573-579. doi: 10.1038/nnano.2011.119

Marzocchi, U., Trojan, D., Larsen, S., Meyer, R. L., Revsbech, N. P., Schramm, A., et al. (2014). Electric coupling between distant nitrate reduction and sulfide oxidation in marine sediment. ISME J. 8, 1682-1690. doi: 10.1038/ismej.2014.19
McGlynn, S. E., Chadwick, G. L., Kempes, C. P., and Orphan, V. J. (2015). Single cell activity reveals direct electron transfer in methanotrophic consortia. Nature 526, 531-535. doi: 10.1038/nature15512

McLean, J. S., Wanger, G., Gorby, Y. A., Wainstein, M., McQuaid, J., Ishii, S. I., et al. (2010). Quantification of electron transfer rates to a solid phase electron acceptor through the stages of biofilm formation from single cells to multicellular communities. Environ. Sci. Technol. 44, 2721-2727. doi: 10.1021/ es903043p

Michalski, A., Damoc, E., Hauschild, J. P., Lange, O., Wieghaus, A., Makarov, A., et al. (2011). Mass spectrometry-based proteomics using Q Exactive, a highperformance benchtop quadrupole Orbitrap mass spectrometer. Mol. Cell. Proteomics 10:M111.011015. doi: 10.1074/mcp.M111.011015

Myers, C. R., and Myers, J. M. (1992). Localization of cytochromes to the outer membrane of anaerobically grown Shewanella putrefaciens MR-1. J. Bacteriol. 174, 3429-3438.

Nakamura, R., Ishii, K., and Hashimoto, K. (2009a). Electronic absorption spectra and redox properties of $\mathrm{C}$ type cytochromes in living microbes. Angew. Chem. Int. Ed. 48, 1606-1608.

Nakamura, R., Kai, F., Okamoto, A., and Hashimoto, K. (2013). Mechanisms of long-distance extracellular electron transfer of metal-reducing bacteria mediated by nanocolloidal semiconductive iron oxides. J. Mater. Chem. A 1, 5148-5157. doi: 10.1039/c3ta01672b

Nakamura, R., Kai, F., Okamoto, A., Newton, G. J., and Hashimoto, K. (2009b). Self-constructed electrically conductive bacterial networks. Angew. Chem. Int. Ed. 48, 508-511. doi: 10.1002/anie.200804750

Nakamura, R., Takashima, T., Kato, S., Takai, K., Yamamoto, M., and Hashimoto, K. (2010). Electrical current generation across a black smoker chimney. Angew. Chem. Int. Ed. 49, 7692-7694. doi: 10.1002/anie.200804750

Nielsen, L. P., Risgaard-Petersen, N., Fossing, H., Christensen, P. B., and Sayama, M. (2010). Electric currents couple spatially separated biogeochemical processes in marine sediment. Nature 463, 1071-1074. doi: 10.1038/ nature 08790

Ntarlagiannis, D., Atekwana, E. A., and Gorby, Y. (2007). Microbial nanowires: Is the subsurface "hardwired"? Geophys. Res. Lett. 34, 1-5. doi: 10.1029/ 2007GL030426

Okamoto, A., Hashimoto, K., and Nakamura, R. (2012). Long-range electron conduction of Shewanella biofilms mediated by outer membrane C-type cytochromes. Bioelectrochemistry 85, 61-65. doi: 10.1016/j.bioelechem.2011. 12.003

Okamoto, A., Hashimoto, K., Nealson, H. K., and Nakamura, R. (2013). Rate enhancement of bacterial extracellular electron transport involves bound flavin semiquinones. Proc. Natl. Acad. Sci. U.S.A. 110, 7856-7861. doi: 10.1073/pnas. 1220823110

Okamoto, A., Nakamura, R., Ishii, K., and Hashimoto, K. (2009). In vivo electrochemistry of C-type cytochrome-mediated electron-transfer with chemical marking. ChemBioChem 10, 2329-2332. doi: 10.1002/cbic.200900422

Okamoto, A., Saito, K., Inoue, K., Nealson, H. K., Hashimoto, K., and Nakamura, R. (2014). Uptake of self-secreted flavins as bound cofactors for extracellular electron transfer in Geobacter species. Energy Environ. Sci. 7, 1357-1361. doi: $10.1039 / \mathrm{c} 3 \mathrm{ee} 43674 \mathrm{~h}$

Pfeffer, C., Larsen, S., Song, J., Dong, M., Besenbacher, F., Meyer, R. L., et al. (2012). Filamentous bacteria transport electrons over centimetre distances. Nature 491, 218-221. doi: 10.1038/nature11586

Pirbadian, S., Barchinger, S. E., Leung, K. M., Byun, H. S., Jangir, Y., Bouhenni, R. A., et al. (2014). Shewanella oneidensis MR-1 nanowires are outer membrane and periplasmic extensions of the extracellular electron transport components. Proc. Natl. Acad. Sci. U.S.A. 111, 12883-12888. doi: 10.1073/pnas.1410551111

Pirbadian, S., and El-Naggar, M. Y. (2012). Multistep hopping and extracellular charge transfer in microbial redox chains. Phys. Chem. Chem. Phys. 14, 13802-13808. doi: 10.1039/c2cp41185g

Reguera, G., McCarthy, K. D., Mehta, T., Nicoll, J. S., Tuominen, M. T., and Lovley, D. R. (2005). Extracellular electron transfer via microbial nanowires. Nature 435, 1098-1101. doi: 10.1038/nature03661

Risgaard-Petersen, N., Kristiansen, M., Frederiksen, R. B., Dittmer, A. L., Bjerg, J. T., Trojan, D., et al. (2015). Cable bacteria in freshwater sediments. Appl. Environ. Microbiol. 81, 6003-6011. doi: 10.1128/AEM.01064-15

Risgaard-Petersen, N., Revil, A., Meister, P., and Nielsen, L. P. (2012). Sulfur, iron-, and calcium cycling associated with natural electric currents running through 
marine sediment. Geochim. Cosmochim. Acta 92, 1-13. doi: 10.1016/j.gca.2012. 05.036

Roels, F. (1974). Cytochrome $c$ and cytochrome oxidase in diaminobenzidine staining of mitochondria. J. Histochem. Cytochem. 22, 442-444. doi: 10.1177/ 22.6.442

Rowe, A. R., Chellamuthu, P., Lam, B., Okamoto, A., and Nealson, K. H. (2015). Marine sediments microbes capable of electrode oxidation as a surrogate for lithotrophic insoluble substrate metabolism. Front. Microbiol. 6:784. doi: $10.3389 /$ fmicb. 2014.00784

Sato, M., and Mooney, M. H. (1960). The electrochemical mechanism of sulfide self-potentials. Geophysics 25, 226-249. doi: 10.1190/1.1438689

Schauer, R., Risgaard-Petersen, N., Kjeldsen, K. U., Tataru Bjerg, J. J., Jørgensen, B. B., Schramm, A., et al. (2014). Succession of cable bacteria and electric currents in marine sediment. ISME. J. 8, 1314-1322. doi: 10.1038/ismej. 2013.239

Seitaj, D., Schauer, R., Sulu-Gambari, F., Hidalgo-Martinez, S., Malkin, S. Y., Burdorf, L. D., et al. (2015). Cable bacteria generate a firewall against euxinia in seasonally hypoxic basins. Proc. Natl. Acad. Sci. U.S.A. 112, 13278-13283. doi: $10.1073 /$ pnas. 1510152112

Seligman, A. M., Karnovsky, M. J., Wasserkrug, H. L., and Hanker, J. S. (1968). Nondroplet ultrastructural demonstration of cytochrome oxidase activity with a polymerizing osmiophilic reagent, diaminobenzidine (DAB). J. Cell Biol. 38, 1-14. doi: $10.1083 /$ jcb.38.1.1

Solomon, E. I., Baldwin, M. J., and Lowery, M. D. (1992). Electronic structures of active sites in copper proteins: contributions to reactivity. Chem. Rev. 92, 521-542. doi: 10.1021/cr00012a003

Straub, K. L., Benz, M., and Schink, B. (2001). Iron metabolism in anoxic environments at near neutral pH. FEMS Microbiol. Ecol. 34, 181-186. doi: 10.1016/S0168-6496(00)00088-X

Suharti, and de Vries, S. (2005). Membrane-bound denitrification in the Grampositive bacterium Bacillus azotoformans. Biochem. Soc. Trans. 33, 130-133. doi: 10.1042/BST0330130

Suharti, Heering, H. A., and de Vries, S. (2004). NO reductase from Bacillus azotoformans is a bifunctional enzyme accepting electrons from menaquinol and a specific endogenous membrane-bound cytochrome c551. Biochemistry 43, 13487-13495. doi: 10.1021/bi0488101

Sulu-Gambari, F., Seitaj, D., Meysman, F. J., Schauer, R., Polerecky, L., Slomp, C. P., et al. (2016). Cable bacteria control iron-phosphorus dynamics in sediments of a coastal hypoxic basin. Environ. Sci. Technol. 50, 1227-1233. doi: 10.1021/acs. est. 5 b0 04369

Sutcliffe, I. C. (2010). A phylum level perspective on bacterial cell envelope architecture. Trends Microbiol. 18, 464-470. doi: 10.1016/j.tim.2010.06.005
Sutcliffe, I. C. (2011). Cell envelope architecture in the Chloroflexi: a shifting frontline in a phylogenetic turf war. Environ. Microbiol. 13, 279-282. doi: 10.1016/j.tim.2010.06.005

Thamdrup, B. (2000). "Bacterial manganese and iron reduction in aquatic sediments," in Advances in Microbial Ecology, Vol. 16, ed. Schink (Boston, MA: Springer).

Vargas, M., Malvankar, N. S., Tremblay, P. L., Leang, C., Smith, J. A., Patel, P., et al. (2013). Aromatic amino acids required for pili conductivity and long-range extracellular electron transport in Geobacter sulfurreducens. mBio 4:e105-13. doi: 10.1128/mBio.00105-13

Vasquez-Cardenas, D., van de Vossenberg, J., Polerecky, L., Malkin, S. Y., Schauer, R., Hidalgo-Martinez, S., et al. (2015). Microbial carbon metabolism associated with electrogenic sulphur oxidation in coastal sediments. ISME J. 9, 1966-1978. doi: 10.1038/ismej.2015.10

Wegener, G., Krukenberg, V., Riedel, D., Tegetmeyer, H. E., and Boetius, A. (2015). Intercellular wiring enables electron transfer between methanotrophic archaea and bacteria. Nature 526, 587-590. doi: 10.1038/nature 15733

Wrighton, K. C., Thrash, J. C., Melnyk, R. A., Bigi, J. P., Byrne-Bailey, K. G., Remis, J. P., et al. (2011). Evidence for direct electron transfer by a Grampositive bacterium isolated from a microbial fuel cell. Appl. Environ. Microbiol. 77, 7633-7639. doi: 10.1128/AEM.05365-11

Yamamoto, M., Nakamura, R., Kasaya, T., Kumagai, H., Suzuki, K., and Takai, K. (2017). Spontaneous and widespread electricity generation in natural deepsea hydrothermal fields. Angew. Chem. Int. Ed. 56, 1-5. doi: 10.1002/anie. 201701768

Yamamoto, M., Nakamura, R., Oguri, K., Kawagucci, S., Suzuki, K., Hashimoto, K., et al. (2013). Generation of electricity and illumination by an environmental fuel cell in deep-sea hydrothermal vents. Angew. Chem. Int. Ed. 52, 10758-10761. doi: 10.1002/anie.201302704

Conflict of Interest Statement: The authors declare that the research was conducted in the absence of any commercial or financial relationships that could be construed as a potential conflict of interest.

Copyright (c) 2018 Kawaichi, Yamada, Umezawa, McGlynn, Suzuki, Dohmae, Yoshida, Sako, Matsushita, Hashimoto and Nakamura. This is an open-access article distributed under the terms of the Creative Commons Attribution License (CC BY). The use, distribution or reproduction in other forums is permitted, provided the original author(s) and the copyright owner are credited and that the original publication in this journal is cited, in accordance with accepted academic practice. No use, distribution or reproduction is permitted which does not comply with these terms. 